\title{
EFEKTIVITAS BETAIN PADA PAKAN AYAM BROILER RENDAH METIONIN BERDASARKAN PARAMETER BERAT BADAN DAN KARKAS
}

\author{
Adi Ratriyanto, Rysca Indreswari dan Sudiyono \\ Jurusan Peternakan, Fakultas Pertanian Universitas Sebelas Maret \\ Email: adir@blog.staff.uns.ac.id
}

\begin{abstract}
This experiment was conducted to investigate the efficacy of methyl groups donor of betaine to spare methionine based on performance and carcass in broiler chickens. In total, 100 day old broiler chickenss were used in this experiment. They were allocated to 4 dieaty treatmants in 5 replicates with 5 broilers each. The basal diet was deficient in methionine. The control diet was obtained from basal diet supplemented with methionine to meet the requirements $5 \mathrm{~g} / \mathrm{kg}$ diet for starter period and $3.8 \mathrm{~g} / \mathrm{kg}$ diet for finisher period. The rest 3 treatments were basal diet deficient in methionine supplemented with 1,2 and $3 \mathrm{~g}$ betaine per $\mathrm{kg}$ diet. The variables that were observed included average daily gain and carcass characteristics. The data were than analyzed by analysis of variance of Completely Randomized Design and continued with Dunnet test. The result indicated that supplementation of $\mathrm{I}$ and $2 \mathrm{~g}$ betaine per $\mathrm{kg}$ diet deficient in methionine resulted the broiler performance which was not different with supplementation of methionine. Accordingly, carcass characteristics for broilers fed diet supplemented with methionine were not different with that supplemented with betaine, which indicated that betaine may reduce the methionine level in the broiler diet. It can be concluded that betaine spares metionine in broiler diets.
\end{abstract}

Key words: betaine, methionine, broilers, performance, carcass

\begin{abstract}
Abstrak: Penelitian ini bertujuan untuk mengetahui efektivitas betain sebagai donor gugus metil berdasarkan parameter berat badan dan karkas. Sebanyak 100 ekor day old chicken (DOC) ayam broiler digunakan dalam penelitian ini, yang dibagi secara acak ke dalam empat perlakuan pakan dengan lima ulangan. Masing-masing ulangan terdiri dari terdiri dari lima ekor ayam broiler. Pakan basal disusun dalam kondisi rendah metionin. Pakan kontrol diperoleh dari pakan basal yang disuplementasi metionin sehingga mencukupi kebutuhan yaitu sebesar $5 \mathrm{~g} / \mathrm{kg}$ pada fase starter dan $3,8 \mathrm{~g} / \mathrm{kg}$ pada fase finisher. Tiga pakan perlakuan lainnya adalah pakan basal yang disuplementasi betain sebesar 1,2 dan $3 \mathrm{~g} / \mathrm{kg}$ pakan. Data yang diamati adalah pertambahan berat badan dan karakteristik karkas. Data yang diperoleh dianalisis statistik menggunakan analisis variansi rancangan acak lengkap dan jika terdapat perbedaan yang nyata dilanjutkan dengan Uji Dunnet. Hasil penelitian menunjukkan bahwa suplementasi betain sebesar $1 \mathrm{~g} / \mathrm{kg}$ dan $2 \mathrm{~g} / \mathrm{kg}$ pakan defisien metionin dapat menghasilkan performan yang setara dengan pakan yang disuplementasi metionin. Suplementasi betain pada pakan defisien metionin dapat menghasilkan karakteristik karkas yang setara dengan suplementasi metionin, yang berarti bahwa betain efektif dalam menghemat penggunaan metionin di dalam pakan ternak unggas. Dapat disimpulkan bahwa suplementasi betain sebesar 1 dan $2 \mathrm{~g} / \mathrm{kg}$ pakan dapat menurunkan penggunaan metionindalampakanayam broiler.
\end{abstract}

Kata kunci: betain, metionin, broiler, performan, karkas 


\section{PENDAHULUAN}

Kecukupan gugus metil yang labil di dalam pakan ternak unggas merupakan suatu hal yang harus mendapat perhatian. Hal ini karena gugus metil tidak disintesis oleh hewan vertebrata, termasuk ternak unggas, sehingga gugus metil merupakan komponen esensial di dalam pakan. Gugus metil ini diperlukan dalam reaksi transmetilasi untuk membentuk substansi-substansi yang penting dalam pertumbuhan seperti karnitin, kreatin, fosfatidilkolin dan epinefrin (Kidd et al., 1997). Donor gugus metil yang potensial antara lain betain, metionin dan kolin, akan tetapi ketersediaan substansi-substansi tersebut tidak setara. Metionin dan kolin digunakan untuk fungsi-fungsi fisiologis penting di dalam tubuh sedangkan betain hanya digunakan sebagai donor gugus metil (Metzler-Zebeli et al.,2009; Ratriyanto et al.,2009). Betain (trimetil glisin) dapat digunakan secara langsung sebagai donor gugus metil, sedangkan kolin harus terlebih dahulu dikonversi menjadi betain. Sementara itu agar dapat berfungsi sebagai donor gugus metil, metionin harus dikonversi terlebih dahulu menjadi Sadenosilmetionin (SAM) hingga akhirnya menjadi homosistein (Pillai et al., 2006; Ratriyanto et al.,2009).

Fungsi metionin untuk sintesis protein dan pembentukan SAM saling berkompetisi terhadap metionin yang tersedia. Oleh karena itu adanya alternatif donor gugus metil dapat mensubstitusi metionin sebagai donor gugus metil, atau menyediakan gugus metil yang diperlukan untuk mengkonversi homosistein menjadi metionin (McDevittet al., 2000; Sun et al., 2008). Kesamaan peran antar abetain dan metionin sebagai donor gugus metil, menyebabkan betain berpotensi menggantikan peran metionin sebagai donor gugus metil, sehingga metionin lebih banyak digunakan untuk sintesis protein dan menghasilkan pertumbuhan ternak yang optimal serta kebutuhan metionin dalam pakan dapat diturunkan. Secara ekonomis, penggunaan betain untuk mensubstitusi metionin dapat menghemat biaya pakan.

Fungsi betain sebagai donor gugus metil menyebabkan betain terlibat pada metabolisme lemak dan protein di dalam tubuh, sehingga memberikan perspektif dalam menghasilkan karkas dengan tingkat perlemakan yang rendah. Betain berpotensi menurunkan deposisi lemak di dalam tubuh dan meningkatkan sintesis protein, sehingga betain merupakan substansi pemodifikasi karkas. Meningkatnya persentase karkas dapat dikaitkan dengan meningkatnya ketersediaan metionin dan sistin untuk deposisi protein, serta berkurangnya sintesis jaringan lemak, misalnya lemak abdominal. Oleh karena itu penelitian ini bertujuan untuk mengetahui tingkat penggunaan betain yang optimal untuk mensubstitusi metionin sebagai donor gugus metil dalam pakan ayam broiler.

\section{MATERI DAN METODE}

Penelitian ini menggunakan 100 ekor DOC ayam broiler, yangdidistribusikan ke dalam 4 perlakuan pakan dengan 5 ulangan. Masing-masing terdiri dari 5 ekor ayam. Ayam ditempatkan dalam petak kandang sehingga setiap ulangan menempati satu petak yang ditentukan secara acak. Tiap petak kandang dilengkapi dengan tempat pakan, air 
minum dan lampu pemanas. Pemeliharaan ayam dilakukan sesuai dengan standar pemeliharaan dari breeder.

Formulasi pakan basal dilakukan untuk memenuhi kebutuhan nutrien ayam broiler fase starter dan finisher sesuai dengan rekomendasi NRC

(1994), kecuali kandungan metionin yang disusun defisien yaitu sebesar $0,375 \%$ pada fase starter dan $0,29 \%$ pada finisher. Susunan pakan basal yang digunakan pada periode pemeliharaan starter dan finisher serta kandungan nutriennya dapat dilihat pada Tabel 1:

Tabel 1. Susunan pakan basal dan kandungan nutrien untuk periode starter dan finisher

\begin{tabular}{lcc}
\hline Ingredien & Starter & Finisher \\
\hline Jagung kuning giling $(\mathrm{g} / \mathrm{kg})$ & 500,0 & 400,0 \\
Dedak padi $(\mathrm{g} / \mathrm{kg})$ & 89,0 & 244,5 \\
Onggok $(\mathrm{g} / \mathrm{kg})$ & 15,6 & 20,0 \\
Bungkil kedelai $(\mathrm{g} / \mathrm{kg})$ & 280,0 & 190,0 \\
Tepung ikan $(\mathrm{g} / \mathrm{kg})$ & 97,0 & 130,0 \\
L-Lysine $\mathrm{HCl}(\mathrm{g} / \mathrm{kg})$ & 1,0 & 2,0 \\
DL-methionine $(\mathrm{g} / \mathrm{kg})$ & 0,4 & 0,0 \\
Tepung kapur $(\mathrm{g} / \mathrm{kg})$ & 10,0 & 7,0 \\
Vitamin mix $(\mathrm{g} / \mathrm{kg})$ & 4,0 & 4,0 \\
Garam dapur $(\mathrm{g} / \mathrm{kg})$ & 2,5 & 2,5 \\
\hline Kandungan Nutrien & & \\
$\quad$ Energi termetabolis $(\mathrm{KCal} / \mathrm{kg})$ & 3200 & 3229 \\
Protein kasar $(\%)$ & 22 & 20 \\
Kalsium $(\%)$ & 1,10 & 1,14 \\
Fosfor $(\%)$ & 0,47 & 0,57 \\
Metionin $(\%)$ & 0,375 & 0,28 \\
\hline
\end{tabular}

Pakan kontrol diperoleh dari
pakan basal yang disuplementasi metionin sehingga mencukupi kebutuhan sesuai NRC (1994) yaitu sebesar $5 \mathrm{~g} / \mathrm{kg}$ pada fase starter dan 3,8 $\mathrm{g} / \mathrm{kg}$ pada fase finisher. Tiga pakan perlakuan lainnya adalah pakan basal yang disuplementasi betain sebesar 1,2 dan $3 \mathrm{~g} / \mathrm{kg}$ pakan. Selama masa adaptasi dari umur 1 sampai 7 hari, ayam akan diberi pakan kontrol secara ad libitum. Pakan perlakuan diberikan mulai umur 8 hari secara ad libitum. Pemeliharaan ayam dilakukan selama 6 minggu.

Peubah yang diamati meliputi pertambahan berat badan, berat potong, persentase karkas dan persentase berat dada. Karkas dinyatakan sebagai persentase dari bobot potong, sedangkan persentase berat dada dinyatakan sebagai persentase dari berat karkas (Sun et al., 2008).Data yang diperoleh dianalisis statistik dengan analisis variansi Rancangan Acak Lengkap (one-way ANOVA). Perbedaan diantara kontrol dengan perlakuan dianalisis dengan uji Dunnet. Tingkat signifikansi yang digunakan adalah $\mathrm{P}<0,05$.

\section{HASIL DAN PEMBAHASAN}

Performan pertumbuhan dari ayam yang mendapat pakan perlakuan dapat dilihat pada Tabel 2. 
Tabel 2.Performan ayam broiler yang diberi pakan perlakuan

\begin{tabular}{lcccc}
\hline & Kontrol & Bet 1 & Bet 2 & Bet 3 \\
\hline $\begin{array}{l}\text { Pertambahan berat badan harian } \\
\quad \text { (g/hari) }\end{array}$ & $61,28^{\mathrm{a}}$ & $59,53^{\mathrm{ab}}$ & $56,97^{\mathrm{ab}}$ & $55,08^{\mathrm{b}}$ \\
Karkas semi eviserasi (\%) & 82,8 & 83,6 & 83,0 & 83,8 \\
Persentasekarkas eviscerasi (\%) & 67,8 & 69,9 & 67,7 & 68,3 \\
Berat dada (\%) & 36,3 & 37,5 & 36,1 & 35,7 \\
\hline
\end{tabular}

${ }^{a, b}$ Superskrip yang berbeda pada baris yang sama menunjukkan perbedaan yang nyata $(\mathrm{P}<0,05)$

Pada Tabel 2 tersebut di atas, terlihat bahwa suplementasi betain sebesar $1 \mathrm{~g} / \mathrm{kg}$ dan $2 \mathrm{~g} / \mathrm{kg}$ pada pakan rendah metionin dapat menghasilkan berat badan yang setara dengan suplementasi metionin. Sementara itu, suplementasi betain dalam pakan defisien metionin dapat menghasilkan karakteristik karkas yang setara dengan suplementasi metionin, yang berarti bahwa betain efektif dalam menghemat penggunaan metionin di dalam pakan ternak unggas. Oleh karena itu betain dapat digunakan untuk mengganti metionin sampai jumlah tertentu pada pakan ternak unggas. Berdasarkan hasil tersebut, maka penelitian ini mendukung hipotesis bahwa betain dapat digunakan untuk menghemat penggunaan metionin pada pakan ternak unggas. Perlakuan pakan standar dengan kandungan metionin cukup dihasilkan pertambahan berat badan harian yang lebih baik $(\mathrm{P}<0,05)$ daripada pakan defisien metionin yang disuplementasi betain $3 \mathrm{~g} / \mathrm{kg}$. Rendahnya performan pertumbuhan pada pakan defisien metionin yang disuplementasi betain $3 \mathrm{~g} / \mathrm{kg}$ diduga karena jumlah akseptor gugus metil lebih sedikit dibandingkan dengan banyaknya donor gugus metil. Hal ini karena betain sebagai donor gugus metil memerlukan akseptor yang dapat menangkap gugus metil dari betain (Ratriyanto et al., 2009). Selain itu, betain merupakan senyawa yang mengandung nitrogen (N) sehingga memerlukan energi untuk mengekskresikannya. Menurut Eklund et al. (2005) tingginya suplementasi betain akan menyebabkan semakin banyak energi yang digunakan untuk mengekskresikan betain dari dalam tubuh ayam dan berkurangnya energi yang digunakan untuk pertumbuhan.

Sampai sejauh ini, efektivitas betain dalam menghemat penggunaan metionin dalam pakan masih menjadi kontroversi (Rostagno dan Pack, 1996; Esteve-Garcia dan Mack, 2000; Pillai et al., 2006). Berbagai argumentasi untuk menjelaskan perbedaan perbedaan efektivitas betain dalam mengganti metionin seperti tersebut di atas masih belum jelas karena beberapa penelitian dilakukan pada kondisi yang berbeda, misalnya adanya cekaman koksidiosis yang dapat meningkatkan respon terhadap betain (Matthews et al., 1997). Sementara itu, karena metionin terlibat pada imunitas selular dan humoral maupun pada integritas jaringan, maka adanya stressor seperti penggantian litter kandang dapat mengalihkan metionin yang seharusnya digunakan untuk sintesis protein dan SAM menjadi digunakan untuk mendukung imunitas dan pemeliharaan jaringan.

Kebutuhan betain bagi ternak sangat dipengaruhi oleh kandungan donor gugus metil di dalam pakan dan 
variasi osmotik di dalam saluran pencernaan maupun organ lainnya. Apabila jumlah betain yang dibutuhkan tidak dapat dicukupi oleh metabolisme di dalam tubuh, maka suplementasi betain pada pakan sangat diperlukan untuk menjaga atau meningkatkan kesehatan dan performan ternak (Ratriyanto et al.,2009). Oleh karena itu, efektivitas betain juga berkaitan erat dengan kandungan total asam amino bersulfur dan donor gugus metil pada pakan (Metzler-Zebeli et al., 2009). Menurut Metzler-Zebeli et al. (2009) pada pakan yang sangat defisien metionin dapat terjadi peningkatan efektivitas betain sebagai donor gugus

\section{DAFTAR PUSTAKA}

Eklund M., E. Bauer, J. Wamatu and R. Mosenthin. 2005. Potential nutritional and physiological functions of betaine in livestock. Nutrition Research Reviews. 18: 31-48.

Esteve-Garcia, E. and S. Mack. 2000. The effect of $D L$-methionine and betaine on growth performance and carcass characteristics in broilers. Animal Feed Science and Technology. 87: 85-93.

Kidd, M.T., P.R. Ferket and J.D. Garlich. 1997. Nutritional and osmoregulatory functions of betaine. World's Poultry Science Journal. 53: 125-139.

Matthews, J.O., T.L. Ward and L.L. Southern. 1997. Interactive effects of betaine and monensinin uninfected and Eimeria acervulina-infected chicks. Poultry Science 76: 1014-1019. metil sebagai akibat kurangnya homosistein untuk remetilasi karena metionin yang disintesis pada proses metilasi digunakan untuk sintesis protein dan tidak diubah kembali menjadi homosistein.

\section{KESIMPULAN}

Berdasarkan hasil yang diperoleh dari penelitian maka dapat diambil kesimpulan bahwa suplementasi betain di dalam pakan ayam broiler dapat meng-hemat penggunaan metionin berdasarkan parameter performan ayam dan karak-teristik karkasnya.

McDevitt, R.M., S. Mackand I.R.Wallis.2000. Can betaine partially replace or enhance the effect of methionine by improving broiler growth and carcass characteristics? British Poultry Science. 41: 473-480.

Metzler-Zebeli, B.U., M. Eklund and R. Mosenthin. 2009. Impact of osmoregulatory and methyl donor functions of betaine on intestinal health and performance in poultry. World's Poultry Science Journal. 65: 419-441,

NRC, National Research Council. 1994. Nutrient Requirements of Poultry. $9^{\text {th }}$ ed. National Academic Press, Washington DC.

Pillai, P.B., A.C. Fanatico, K.W. Beers, M.E. Blair and J.L. Emmert. $2006 . \quad H o m o c y s t e i n e$ remethylation in young broilers fed varying levels of methionine, choline, and betaine. Poultry Science, 85: 90-95. 
Ratriyanto, A., R. Mosenthin, E. Bauer and M. Eklund. 2009. Metabolic, osmoregulatory and nutritional functions of betaine in monogastric animals. AsianAustralasian Journal of Animal Sciences, 22: 161-1476.

Rostagno, H.S. and M. Pack. 1996. Can betaine replace supplemental DLmethionine
diets?Journal of Applied Poultry Research 5: 150-154.

Sun, H., W.R. Yang, Z.B. Yang, Y. Wang, S.Z. Jiang and G.G. Zhang. 2008. Effects of Betaine Supplementation to Methionine Deficient Diet on Growth Performance and Carcass Characteristics of Broilers. American Journal of Animal and Veterinary Sciences. 3: 78-84. 